DOI: $10.20396 /$ urbana.v10i3.8651524

\title{
Distopia e Reparação POLÍtICA NA CEILÂNDIA de ADIRLEY QUEIRÓS
}

\section{DYSTOPIA AND POLITICAL REPARATION IN CEILÂNDIA BY ADIRLEY QUEIRóS}

Mariana Lucas Setúbal Pontifícia Universidade Católica de São Paulo - PUC SP mlsetubal@faap.br

\section{Resumo}

O presente artigo propõe uma reflexão sobre os dois longas metragens do diretor Adirley Queirós: " A Cidade é uma só?" (2011) e "Branco sai, preto fica" (2014). A análise é norteada pela temática da disputa territorial, trabalhando as cidades satélites e o Plano Piloto enquanto alegoria da democracia brasileira. À medida em que esta disputa faz emergir as contradições do projeto de modernização nacional, convoco a noção de demofobia ( $L Y N C H, 2014)$ com o intuito de compreender o processo de construção do Brasil contemporâneo, onde a nova capital foi erguida como farol de uma [falsa] utopia.

\section{Palavras-chave}

Adirley Queirós. Arquitetura. Cinema. Brasília. Ceilândia. Disputa territorial. Demofobia.

\section{Abstract}

The present article proposes a reflection on the two feature length films directed by Adirley Queirós: "A Cidade é uma só?" (2011) e "Branco sai, preto fica" (2014). The analysis in question is guided by the territorial dispute: satellite cities and the Pilot Plan, as an allegory of the limits of Brazilian democracy. As this dispute brings out the contradictions of the project of national modernization. I call the notion of demophobia ( $L Y N C H, 2014$ ) in order to understand the articulation of this concept in the process of building Brazilian democracy, where the new capital is erected as a beacon of utopia.

\section{Keywords}

Adirley Queirós. Architecture. Cinema. Brasília. Ceilândia. Territorial dispute. Demophobia. 
Brasília é uma grande ficção. Assim, Adirley Queirós inicia, no Festival Adaptação, sua na mesa de "Disputa pela cidade". Morador da Ceilândia, cidade satélite do Distrito Federal (DF), refere-se ao local como o primeiro "aborto territorial" - o nome parte da abreviação de Campanha de Erradicação de Invasões (CEI) mais o sufixo "lândia". A campanha se configurou enquanto programa de "limpeza urbana" que transferiu cerca de 100 mil trabalhadores para uma região afastada, sem nenhum tipo de infraestrutura, a $30 \mathrm{Km}$ do Plano Piloto. O programa foi iniciado durante os primeiros anos da ditadura militar, em 1969 e dois anos depois a Ceilândia era inaugurada.

A chegada dos candangos para construção da nova capital gerou um cenário inesperado: o Plano Piloto não reservara lugar para eles. O arquiteto Lucio Costa, autor do projeto urbanístico da nova capital, e o governo não imaginavam que o fluxo migratório teria um caráter permanente. No primeiro ano da construção, Brasília recebeu 65 mil trabalhadores, dos quais apenas 3,5\% estavam alocados em um espaço planejado, 10,3\% em locais preexistentes e $86,5 \%$ em espaços provisórios e ilegais. À medida que a data de inauguração se aproximava, o fluxo migratório aumentava e o problema de alocação dessa população se agravava.

Meus pais foram expulsos de Brasília, sou da primeira geração pós aborto territorial. Moro em Ceilândia, periferia de Brasília, há mais de 30 anos. Eu me tornei cineasta e grande parte de meu trabalho está relacionada a este tema. Tudo aquilo que sou, que penso, tudo aquilo que minha geração é, como ela age, é fruto desta contradição de ser e não ser de Brasília (QUEIRÓS, apud SABOIA e SANDOVAL 2012:4).

O projeto de Lucio Costa e Oscar Niemeyer buscava romper com uma concepção de cidade ainda muito marcada pelo que o modernismo considerava uma caótica arquitetura colonial. Brasília é projetada não apenas enquanto subversão da malha urbana, mas sobretudo enquanto projeto embrionário de uma nova sociedade que assumiria como valor fundante a modernização. A história narrada é familiar a todos os brasileiros, mas seria a cidade uma só?

O ideário de racionalização presente no projeto de Lucio Costa buscava desenvolver um modelo de urbanização capaz de anular a estratificação social, tornando a convivência entre "ricos" e "pobres" pacífica e organizada. Mas ele é posto em xeque quando se criam as cidades-satélites. Desordenadas e mal planejadas, elas passam a ser vistas como "como um contraponto à Brasília" (CEBALLOS 2014: 54), um espaço de exceção que acentua as contradições do símbolo modernista e expõe conflitos territoriais. Assim, Taguatinga, Núcleo Bandeirante, Gama, Sobradinho, Samambaia, Santa Maria, Morro do Urubu e Ceilândia seriam a consolidação do fracasso do projeto moderno e, portanto, a certeza da impossibilidade de 
neutralizar a segregação sócio espacial, pretendida em sua concepção, quando menos de $10 \%$ da população habita o Plano-Piloto. A constatação é irrefutável: o símbolo não resistiria a realidade.

\section{Brasília, a utopia moderna sem povo}

Brasília era a meta síntese do plano de governo de Juscelino Kubitschek, o Programa de Metas, que servia como a alavanca que lançaria o Brasil no seio da modernidade. Foi o primeiro e, possivelmente, o mais ambicioso programa de modernização já apresentado no país; tinha o objetivo de efetivar mudanças significativas na estrutura produtiva nacional internacionalizando diversos ramos importantes, a começar pela indústria automobilística.

A nova capital seria uma medida necessária para atenuar o desequilíbrio regional do país; em 1960 o Norte e o Centro-Oeste, com 64\% da superfície territorial, contavam com apenas $7 \%$ da população. A construção de um pólo administrativo no interior do país, contribuiria para um aumento na densidade demográfica e como consequência disso o surgimento de novas fontes de riqueza e comércio através da ocupação do território. $O$ pensamento geopolítico, por sua vez, argumentava que uma capital no Planalto Central militarmente seria menos vulnerável. Milton Santos lembra que, entre os defensores de Brasília, Pedroso da Silveira "considerava impossível vencer a inflação sem a mudança da capital". A seu ver a transferência da sede do governo despertaria um maior interesse pelas diversas regiões do país, assim sendo, haveria um fomento nas atividades econômicas, que afetaria diretamente a distribuição de renda, e implicaria em uma redução da desigualdade, impactando diretamente os índices de inflação. "A seu ver, a inflação resultaria menos do excesso de meios de pagamento do que da sua inadequada circulação nas diversas regiões" (SANTOS 2012: 127).

A construção a nova capital era uma iniciativa que permitia a convergência de múltiplos interesses e expectativas. Essas justificativas rapidamente legitimam a proposta de mudança da capital, dando início a uma das empreitadas mais ousadas da história do país. "Vontade criadora e subdesenvolvimento do país são (...) os termos que afrontam a realização efetiva de Brasília. É da sua confrontação que a cidade retira os elementos de sua definição atual" (SANTOS 2012: 127). A vontade criadora de Lucio Costa, Oscar Niemeyer e Juscelino Kubitscheck encontra espaço na tabula rasa do Planalto Central. Mas o subdesenvolvimento se faz presente enquanto elemento de oposição a esta utopia do progresso, fazendo de Brasília outra típica capital latino-americana, marcada pela dualidade latente entre progresso e atraso. 
Apartar o centro político-administrativo "das áreas onde se desenvolve o processo vital de crescente identificação entre sua história 'natural' e sua história cultural e política" (PEDROSA 2012: 35), instaura uma dinâmica em que o aparelho do Estado isolado assume vida própria, independente de reivindicações e necessidades populares, e passa a ser ditado a partir dos interesses políticos e econômicos de uma pequena minoria. Portanto, a "classe política" blindada na armadura de concreto do Plano Piloto segrega o povo dos dirigentes políticos, o aparelho de estado dos principais centros urbanos, poder do povo, de forma a garantir o desenvolvimento de uma nova burocracia tecnocrata cindida da vida nacional do país.

Fatalmente isolada do povo, o seu governo desconhecerá, não participará senão de fora do drama de seu crescimento, do amadurecimento de sua cultura, da formação de sua personalidade. Brasília seria uma espécie de casamata impermeável aos ruídos externos, aos choques de opinião como um estado-maior que se abrigasse em cavernas subterrâneas blindadas para, no comando das operações, escapar aos bombardeios e aos ataques dos teleguiados inimigos numa guerra atômica futura (PEDROSA 2012: 35).

A urgência obsessiva que marcou a construção de Brasília fez emergir aspectos cruciais para reflexão. A fixação de um prazo de quarenta e dois meses para o erguimento de uma cidade em um planalto semidesértico, onde até então nenhum estabelecimento humano havia sido erguido tornou evidente um espectro que assombrava o Brasil de Juscelino: o espectro da modernidade. Como anunciava Mario Pedrosa, "o Brasil está condenado ao moderno". Segundo ele, o imaginário do recomeço é um dos elementos atávicos da constituição nacional. A América Portuguesa era, desde o período colonial, um local onde se poderia começar de novo, e Brasília é o grande paradigma do recomeço.

Havia no planejamento um certo conservadorismo institucionalizado, que era edificado às pressas. Marcelo Roberto apontava, em artigo no Correio da Manhã (24/03/1957), para o anacronismo presente na concepção dos edifícios dos ministérios. Dentre de todas as contradições e anacronismos presentes no planejamento de Brasília, talvez o mais emblemático seja a presença dos ministérios da Marinha, Aeronáutica de Guerra no lugar de um Ministério de Defesa.

No seu plano, Lúcio Costa prevê ao longo do Eixo Monumental da cidade, acima do setor municipal, além das garagens da viação urbana, em seguida, de uma banda e de outra, os quartéis. Que quartéis são esses? São mesmo, segundo ele os quartéis de tropa do Exército. Dir-se-ia prever uma transplantação da Vila Militar para Brasília (...) Primeiro é de se perguntar: para que esses quartéis dentro da cidade? Segundo quais as funções específicas dessas tropas, quando a nova capital situada por isso mesmo no 
Planalto Central, a centenas e milhares de quilômetros do litoral se acha ao abrigo de um súbito desembarque inimigo que só pode ser alcançada pelo ar (COSTA, 1957 apud PEDROSA, 2012: 40-41).

\section{Monumento, autoria e tecnocracia}

O projeto de Brasília era uma legítima tabula rasa também por toda concepção arquitetônica estar nas mãos de Oscar Niemeyer e de Lucio Costa. Ambos se deparavam com uma oportunidade única de materializar concepções e teorias sobre cidade contemporânea no Planalto Central árido e, então, pouco habitado. As condições tornavam-se ainda mais promissoras quando somadas ao entusiasmo do presidente Juscelino Kubitscheck, que enxergava no projeto de Brasília o futuro do Brasil.

De uma ideia que jamais se fixara em minha mente a uma sugestão que fui obrigado, por coerência e honra da palavra empenhada, a estudar mais detidamente - a construção de Brasília - súbito surgia em toda sua importância geoeconômica. De uma das metas do meu plano de governo, a nova capital federal se transformaria, por assim dizer, naquela que uniria e daria amplitude a todas as outras. (KUBITSCHECK, 2012: 140)

Definido o planejamento da capital, a dimensão monumental torna-se um dos principais elementos constituintes do projeto, "monumento não no sentido de ostentação, mas no sentido de expressão palpável, daquilo que vale e significa" (COSTA 2012: 145).

O sentido original do termo monumento é derivado do latim monumentum, que por sua vez é derivado de monere, que significa advertir ou lembrar. O monumento permitiria, nesse sentido, a ativação, o resgate de uma memória. Tanto para aqueles que o edificam quanto para aqueles aos quais se destina, o monumento ergue-se enquanto defesa frente ao esquecimento, enquanto lembrança, se materializando sob variadas formas: túmulos, templos, arco de triunfo, colunas, obeliscos...

A especificidade do monumento deve-se precisamente ao seu modo de atuação sobre a memória. Não apenas ele trabalha e a mobiliza pela mediação afetiva, de forma que lembre o passado fazendo-o vibrar como se fosse presente. Mas esse passado invocado, convocado, de certa forma encantado, não é um passado qualquer: ele é localizado e selecionado para fins vitais, na medida em que pode, de forma direta, contribuir para manter e preservar a identidade de uma comunidade étnica ou religiosa, nacional, tribal ou familiar. (CHOAY 2001: 18)

Entretanto a função rememorativa original perde gradualmente sua importância na sociedade moderna, o monumento passa, a partir do século XVII, a denotar poder, grandeza e beleza: "um edifício construído para eternizar a lembrança de coisas memoráveis, ou 
concebido, erguido ou disposto de modo que se torne um fator de embelezamento e de magnificência nas cidades" (QUINCY apud CHOAY 2001: 19). Ainda assim, a dimensão mnemônica continuava presente nesta evolução de sentido do "monumento" à medida em que há uma maior preocupação no efeito produzido pelo edifício do que em sua destinação.

Hoje, o sentido de "monumento" alterou-se mais. Para além do estético o deslumbre técnico torna-se crucial para que o monumento cumpra sua função, seja através do encantamento, seja pelo espanto. O domínio da técnica passa a ser essencial para que o monumento cumpra sua finalidade, se impondo "à atenção sem pano de fundo, atua[ndo] no instante, substituindo seu antigo status de signo pelo de sinal" ( $\mathrm{CHOAY}$ 2001: 20). Portanto, a função memorial do monumento vai se extinguindo, substituindo progressivamente o ideal de memória pelo ideal da técnica.

O monumento histórico, diferentemente do monumento moderno, não é uma criação premeditada; sua função mnemônica é atribuída posteriormente à sua edificação, através das práticas sociais e dos olhares de historiadores e dos artistas. Todo objeto do passado, seja este edifício ou não, pode ser compreendido enquanto testemunho histórico de seu tempo, sem que para isso tenha tido em sua origem uma finalidade memorial. De modo inverso, qualquer artefato humano pode ser investido de uma função memorial.

Isto posto, surge a questão: qual é a função memorial atribuída ao monumento de Brasília? Brasília como monumento não possui função de rememoração, surgindo, ao contrário, enquanto paradigma de futuro, enquanto superação do passado - um monumento, portanto, ao apagamento. Sem lastro do passado histórico, Brasília é sustentada por seu valor simbólico, desvinculado do valor utilitário; a nova capital constitui-se enquanto signo à medida que é transformada na imagem do futuro do país.

Mas o rompimento do passado, no caso da nova capital, não resultou em qualquer movimento dialético em que o sentido histórico original fosse assumido de forma a ressignificá-lo, atribuindo um novo sentido simbólico ao monumento. Muito pelo contrário, Brasília surge do sonho de recomeço, e a memória candanga, que constitui os primeiros anos de vida da capital, é suprimida pela narrativa oficial.

Para Françoise Choay, "indivíduos e sociedade não podem preservar e desenvolver sua identidade senão pela duração e pela memória" (CHOAY 2001: 112). É indiscutível que a memória candanga não integra esse projeto de construção de identidade que Brasília representou. Em seu poema "Perguntas de um operário que lê" Bertolt Brecht aponta para o cerne desta aporia: "Quem construiu Tebas, a das sete portas?/ Nos livros vem o nome dos reis,/ Mas foram os reis que transportam as pedras?/ Babilônia, tantas vezes destruída/Quem 
outras tantas a reconstruiu?". Como todo monumento da alta cultura, a capital brasileira não poderia existir sem o trabalho dos produtores diretos, no caso de Brasília, os candangos. Brasília se constituiria, dessa ótica, em um monumento de barbárie

O projeto de Lucio Costa e Oscar Niemeyer reivindicava uma arquitetura com lastro social (NIEMEYER 2012:147), capaz de garantir espacialmente a anulação da estratificação das classes sociais. Brasília é concebida não apenas como subversão da malha urbana típica, que normalmente é demarcada pelo acesso à serviços e facilidades distribuídos diferencialmente conforme as classes sociais, mas também como projeto embrionário de uma nova sociedade que assumiria como valor fundante o igualitarismo. Mas Brasília nasce da injustiça, da opressão, do apagamento da memória, da super-exploração do trabalho, do autoritarismo. $O$ monumento de tabula rasa é incapaz de apagar as contradições do passado; muito pelo contrário, ele as atualiza e as lança no tempo presente com ainda mais força.

E um muro de discriminação se estabeleceu entre nós e os nossos irmãos operários. Nós sentimos que foi uma fase que nos enganamos, que a coisa ia mudar. Viver o sonho de JK foi algo muito importante para o Brasil, era mesmo um clima de otimismo. Mas quando ela a inaugurou, nós sentimos essa transformação nós vimos que Brasília nunca ia ser a cidade do futuro, mas uma cidade como qualquer outra. Então sentimos com um pesar esse desengano dos que vieram construir Brasília, que vieram de todos os pontos do país, do Nordeste principalmente, esses nossos irmãos que vieram para Brasília nos ajudar que construíram os palácios, apartamentos, as escolas, tudo isso e de nada disso usufruíram, saíram de Brasília mais pobre ainda, e foram morar longe da cidade que construíram. Vendo ela de longe como um sonho frustrado, como Drummond dizia que via Itabira. De modo que esse aspecto negativo de Brasília, mas que nós devíamos ter compreendido desde do início, quer dizer, Brasília não representa a cidade do futuro, a cidade do futuro que pensamos era de homens iguais. (NIEYMEYER In Conterrâneos velhos de guerra, 1991, 36'56")

\section{Brasília, monumento do "autoimperialismo"}

Em seu ensaio "O Autoimperialismo", Benjamin Moser analisa três das principais cidades brasileiras: São Paulo, Rio de Janeiro e Brasília, identifica nestas características comuns, que apontam para uma cultura predatória e autoritária. O conceito que marca sua análise é o do auto-imperialismo, uma relação de opressão imperialista que as elites brasileiras estabelecem com o povo do país, e que Moser remete à mais antiga das imagens do imaginário nacional, a da antropofagia.

Depredar-se, destruir-se, invadir-se, devorar-se é uma constante em nossa história. O Brasil sempre consumiu a si mesmo. Moser estende a metáfora à prática de deglutir seu próprio povo e território, para analisar uma retórica patriótica em que seu único propósito é o enriquecimento daqueles vieram para espoliar o território. 
Há, para o autor, um elemento atávico que marca nossa historiografia. Se aquilo que norteia a historiografia norte-americana é o medo do declínio, a historiografia brasileira é, em contrapartida, assombrada pelo espectro do progresso, em uma espécie de movimento teleológico que conduziria do atraso à modernidade. A relação com o progresso no Brasil era uma crença instrumental e uma esperança de que o país, à medida que deslanchasse, deixaria seu passado para trás (MOSER 2016: 27).

À vista disto, acreditar no progresso não era acreditar no Brasil. Não consistia em crer que algo positivo poderia vir de nossa história, era exatamente o contrário: "consistia em ter esperança de que a história do país podia ser negada. Consistia em acreditar de que o Brasil poderia fugir de si mesmo" (MOSER 2016: 28).

A Brasília monumental torna explícita essa contradição. O Plano-Piloto deixa escancarada a face imperialista do Brasil.

Os brasileiros se dizem diferentes dos outros povos latino-americanos. De modo geral, eu tendia a associar essa insistência a certo nacionalismo maçante frequente na vida brasileira. (...) - O Brasil era tão latino-americano quanto desbragadamente imperialista. 'Nós' imaginávamos que um país tinha que escolher entre um e outro. Mas hoje me causa estranhamento que essa ideia possa ter me causado estranhamento (MOSER 2016: 100).

Brasília é um monumento do auto-imperialismo por excelência, alocado em um país que sempre fora um lugar a ser conquistado, não pelos estrangeiros, mas sim, pelos próprios brasileiros.

A capital brasileira era o símbolo máximo de um Terceiro Mundo em ascensão, a esperança para todos no país que lutavam para romper com sua condição colonial e galgar um espaço no palco das nações. A história do período pós-colonial sempre se orientou pela perspectiva de um futuro promissor, mas o que Brasília fez (e faz) é empurrar a nação de encontro com seu passado autoritário e oligárquico.

Inaugurada a capital, o Estado rapidamente expulsou:

(...) os pobres para periferia, segregou os funcionários públicos e parlamentares em unidades residenciais fundamentalmente idênticas - as superquadras -, de acordo com uma concepção hierárquica e segmentada da vida social, e acentuou a presença esmagadora do Estado empregador. Por outro lado, Juscelino não era alheio a nada do mundo da política e tinha de saber que o gesto da transferência da capital trazia de contrabando um efeito perverso: contribuía para o isolamento do centro de poder, distanciava o governo das demandas sociais crescentes e alienava o governante do contato do povo (SCHWARCZ E STARLING 2015: 429). 


\section{A tradição demofóbica brasileira}

A mudança da capital para o centro do país não era nenhuma novidade. A ideia já estava prevista na Constituição de 1934. Debatida em diversas ocasiões, a proposta desaparece durante o Estado Novo. Com a queda de Getúlio e a eleição de Juscelino Kubitscheck, esse assume para si a tarefa. O "presidente bossa nova", que impulsionaria o desenvolvimentismo do país, descontextualiza a real motivação da mudança da capital e a reveste de um discurso integrador, onde a mudança para o centro do país seria necessária para promover um Brasil conectado - de leste a oeste, de norte a sul. O discurso oficial forja o mito de Brasília.

A narrativa construída por Kubitscheck oficializa a versão do desenvolvimento do interior a partir da mudança da capital, mas suprime a informação de que o então presidente estava cumprindo um desígnio institucional firmemente estabelecido nas oligarquias brasileiras, retirar a capital do país do conturbado Rio de Janeiro, onde as massas pressionavam o poder central. Apresentada como tabula rasa do passado, "a nova capital não guardaria nenhuma lembrança de 140 anos anteriores de vida independente" (LYNCH 2014: 280).

Para Christian Lynch há um elemento que caracteriza e obstaculiza o processo de construção da democracia brasileira, o caráter demofóbico de suas elites. Em seu estudo da história institucional e pensamento político brasileiro da independência até 1930, Lynch (2014) identifica um sentimento demofóbico por parte da "classe política" brasileira. Esse traço, também destacado por Felix Sánchez (2017), é "onipresente na história política do país, chegando a se expressar com intensidade em momentos marcados pela ascensão das lutas das classes trabalhadoras, em sentido amplo - como aconteceu nos ciclos políticos que levaram ao golpe de 1964, à ascensão do governo Collor em 1989 e ao golpe contra o governo da Dilma em 2016" (SÁNCHEZ, 2017, p.10).

Lynch parte do conceito de demofobia desenvolvido pelo filósofo Marc Crépon para o contexto francês:

Denomina-se demofobia todo o método de escamotear ou de rejeitar a 'palavra' do povo, decorrente de alegria, apreensão ou desconfiança suscitada por este mesmo povo, que é reputado 'ignorante' na medida em que acabaria vítima de suas próprias afeições, sejam elas excessos de paixão ou, ao contrário, completa indiferença. A demofobia é manifestada pelos governos, sempre que, confrontados por meio de 
contestações ou reivindicações populares que os incomodam, eles tentam minimizar aquela 'palavra' ou desacreditá-la. Mas ela constituiu também o ponto cego comum dos teóricos que fustigam as 'derivas' da democracia e desconfiam das eleições e seus resultados, quando the recusam toda e qualquer legitimidade (CRÉPON 2012 apud LYNCH 2014: 250).

Por conseguinte, é possível compreender no ato da mudança da capital para o interior do país uma medida demofóbica. A transferência da capital permitiria conter os malefícios decorrentes das pressões populares sobre o Governo Federal, ao passo que no Rio de Janeiro ele ficaria a mercê de "uma população mestiça, altamente emotiva, num ambiente irritante de estufa, [que] não parece ser a sede mais indicada para uma administração eficiente, capaz de exercer com o âmbito nacional" argumentava Osvaldo Meira Penna, escritor e diplomata brasileiro constantemente citado por Juscelino. O goiano Peixoto da Silveira seguia a mesma linha de argumentação: "o Rio tende a ser cada vez mais uma cidade de vida difícil e consequentemente um foco de inquietação social (...) O governo supremo do país precisa funcionar em um ambiente tranquilo".

A ideia de que Rio de Janeiro era habitado por uma massa de potenciais revoltosos tornava necessário manter o aparelho de Estado afastado daí para permitir um exercício "adequado" do poder. Israel Pinheiro, futuro presidente da companhia encarregada pela construção de Brasília, a NOVACAP, defendia que:

Uma cidade como o Rio, pela sua amplitude e pela sua adiantada industrialização, com a consequente concentração das grandes massas, obriga o governo federal, pelo simples fato de estar sediado, a permanentes preocupações com assunto de ordem meramente local, desviando-lhe a atenção, com prejuízo dos problemas nacionais. Asfixiando sob a onda de interesses particulares, ainda que legítimos, está o governo federal, por força, divorciado daqueles brasileiros que, no interior, também constroem, silenciosamente, e tantas vezes ao desamparo de qualquer ação governamental, a riqueza do país. As agitações sociais de caráter grave, fermentam, de preferência, nos grandes centros, insufladas por elementos de indisciplina e desordem, os quais têm aí as condições ideais para subversão. (PINHEIRO, 1962, apud LYNCH, 2014:282)

Posteriormente, diante da mobilização das massas cariocas em 1962 para impedir a adoção pelo Congresso, da solução parlamentarista que enfraqueceria João Goulart, o então ex-presidente Juscelino Kubitscheck declarava que teria sido Brasília quem garantiu a ordem democrática.

A democracia brasileira dificilmente poderia resistir a uma prova como essa a que foi submetida no segundo semestre de 1961, se a sede do governo federal tivesse continuado no Rio de Janeiro. Foi Brasília fator preponderante na manutenção do clima 
de ordem e confiança que permitiu ao Congresso reunir-se com a necessária liberdade de movimentos e deliberar sem agitações e pressões de massa. Brasília, só por isso já foi justificada. (KUBITSCHECK, 1962, apud, LYNCH, 2014: 283)

Há um discurso antiurbano na escolha da troca da capital. Brasília, ao mesmo tempo que é modelo de cidade modernista, é anticidade, na medida em que foge das condições essenciais de vida urbana: povo, mistura, conflito. Em consequência disto, é evidente que o projeto de Lucio Costa e Oscar Niemeyer é um escândalo como capital de uma democracia; manter a população distanciada, isolada e controlada só faria sentido em um governo autoritário. Não à toa, logo depois de sua inauguração, é instaurada a ditadura militar brasileira, e Brasília adequou-se à função da capital de um regime ditatorial de maneira assombrosa.

Nestes termos, analisar a questão da territorialidade no cinema de Adirley Queirós, é compreender o signo espacial enquanto forma alegórica dos limites da democracia brasileira. $\mathrm{Na}$ esteira dessa reflexão cabe, portanto, compreender os filmes: "A cidade é uma só?" e "Branco sai, preto fica", não enquanto trato de uma exclusão original, mas sobretudo enquanto crítica de uma existência popular abortada, constituída às margens do que é reconhecido como sociedade pelas elites no poder.

\section{Brasilidade inconformada}

Há, na obra de Adirley Queirós, o reconhecimento do fracasso do Brasil enquanto projeto. As principais empreitadas reformistas da história do país não atingiram seus objetivos finais. Tanto o Plano de Metas de Juscelino quanto o lulismo reciclaram mecanismos extremamente perversos de manutenção das estruturas conservadoras vigentes. São estas contradições que os filmes procuram apontar.

Se, em seu primeiro longa-metragem "A cidade é uma só?", há uma crítica ao projeto de modernização nacional, partindo do signo de Brasília enquanto alegoria do auto-imperialismo, em "Branco sai, preto fica" o diretor identifica as contradições do projeto de inclusão que orientou, nas últimas décadas, a política do país, partido do questionamento do espaço efetivamente conquistado por uma classe que ascendeu materialmente, mas segue negligenciada pelo Estado, que ainda Ihe nega os direitos básicos de cidadãos.

Assim sendo, me parece que o filme "A cidade é uma só?" arma o território para a denúncia que irá ser consolidada em "Branco sai, preto fica", ao passo que é possível identificar nos filmes uma estrutura de sentimento de uma brasilidade inconformada, que marca o desenvolvimento narrativo. 
O conceito de Raymond Williams de estrutura de sentimento ${ }^{1}$ torna-se central para compreender as referências com as quais Adirley Queirós está dialogando, à medida em que os filmes analisados são produzidos em uma conjuntura muito específica, crucial para a compreensão da crítica presente nos filmes. "A cidade é uma só?" é lançado em 2011 e "Branco sai, preto fica" em 2014: entre eles ocorrem as manifestações de junho de 2013, que marcam uma ruptura na história política recente do país. Portanto, é possível reconhecer nos filmes o esgotamento de um projeto político que não realizou sua promessa. Os protestos de junho sinalizam o forte desgaste que o sistema político vinha enfrentando desde o "mensalão" (2005), processo que implicou na prisão de parte dos líderes petistas, entre eles o poderoso ex-ministro da Casa Civil, José Dirceu. O escândalo do mensalão ocorre em meio a uma conjuntura econômica internacional favorável, marcada pelo boom das commodities, o que garante não apenas a continuidade dos programas sociais, mas sobretudo sua ampliação. Graças às condições econômicas e ao carisma do então presidente Luís Inácio Lula da Silva a crise é estancada e o sistema se recupera. Depois de 2010, quando Dilma Rousseff é eleita presidente, o contexto já é outro e a conjuntura econômica global retrai significativamente.

Já em seu primeiro mandato Dilma Rousseff (2011-2014) enfrentou alguns entraves tanto de ordem econômica quanto em relação com "os aliados". A política econômica adotada pela presidenta seguia a mesma linha adotada por Lula, na qual "os recursos provenientes de exportações permitiam medidas redistributivas de forte apelo popular". Mas, no novo cenário, "o governo Dilma assistiu um gradativo estreitamento de sua margem de manobra pela deterioração das finanças públicas, redução dos níveis de crescimento e aumento do desemprego" (CORREA e GHIROTTO 2016: 5). É este o contexto que marca as manifestações de junho de 2013.

As mobilizações desestabilizaram todo o sistema político, alarmando políticos de todos os partidos: 24 milhões de pessoas foram às ruas reivindicar melhoria no transporte público, na educação e na saúde e medidas contra o sistema político corrupto vigente.

Essas manifestações, que não conseguiram promover as mudanças demandadas, tiveram dois repiques importantes. A primeira, no segundo turno da campanha presidencial de 2014, quando a candidata Dilma derrota o candidato tucano Aécio Neves em uma disputa polarizada que recupera a mobilização dessa parcela que havia ganho as ruas em 2013. Paralelo a isso, a polarização social que já havia se instalado

\footnotetext{
1 "A noção de estrutura de sentimento foi criada para focalizar uma modalidade de relações históricas e sociais que ainda era totalmente interior à obra, e não dedutível de uma ordenação ou classificação externa. Ou seja, trata-se de descrever a presença de elementos comuns em várias obras de arte do mesmo período histórico que não podem ser descritos apenas formalmente, ou parafraseando como afirmativas sobre o mundo: a estrutura de sentimento é a articulação de uma resposta a mudanças determinadas na organização social" (CEVASCO 2001: 152-153).
} 
com as manifestações de 2013 avança nas classes médias urbanas, que ganham autonomia desenvolvendo uma linha ativa de protesto galvanizada por ações com um verniz conservador, racista, homofóbico e xenofóbico em torno da ideia de denúncia ao "lulismo", ao "petismo" a "esquerda". Esse componente ganha a adesão de praticamente todos os que votaram em Aécio Neves no segundo turno de 2014 (SANCHEZ 2017: 17).

Os filmes de Adirley Queirós expõem o paradoxo da utopia progressista. Tanto em "A cidade é uma só?" quanto em "Branco sai, preto fica" há o reconhecimento da violência enquanto elemento constitutivo da narrativa oficial. Como se na história brasileira houvesse uma urgência em apagar tudo aquilo capaz de revelar as contradições dos projetos de desenvolvimento nacional.

\section{6. "Da nossa memória fabulamos nós mesmos"}

As cidades satélites demarcam, em seu projeto, um estado de exclusão permanente, e a Ceilândia emerge enquanto retrato do projeto de democracia brasileira. A distância entre as cidades-satélites e o Plano Piloto, é reforçada ao longo dos filmes a ponto de tornar intransponível a passagem da primeira para a segunda - é necessário um passaporte para se deixar a periferia e adentrar o centro da Capital Federal. Tanto em "A cidade é uma só?" quanto "Branco sai, preto fica" a fotografia do filme mostra-se muito mais à vontade nas ruas estreitas e nas casas subterrâneas da Ceilândia - onde o progresso não chegou e não simula uma falsa democracia - do que na utopia modernista do Plano Piloto.

O signo da disputa territorial no cinema de Adirley Queirós marca a entrada na discussão política e sustenta o debate estético. O resgate das narrativas silenciadas é garantido por meio da forma documental, que, ao mesmo tempo, partilha a experiência traumática e a fabulação da memória oprimida enquanto ferramenta de combate ao poder público. "Da nossa memória fabulamos nós mesmos" anuncia a legenda final do filme "Branco sai, preto fica". Na dimensão política, a Ceilândia apresenta um estado de exclusão permanente que se inicia com o Plano de Metas do JK, atravessa a ditadura militar brasileira e permanece nas políticas de inclusão que são apresentadas como uma marca dos anos do PT no poder; o desenvolvimentismo sempre nos condena à exclusão. 


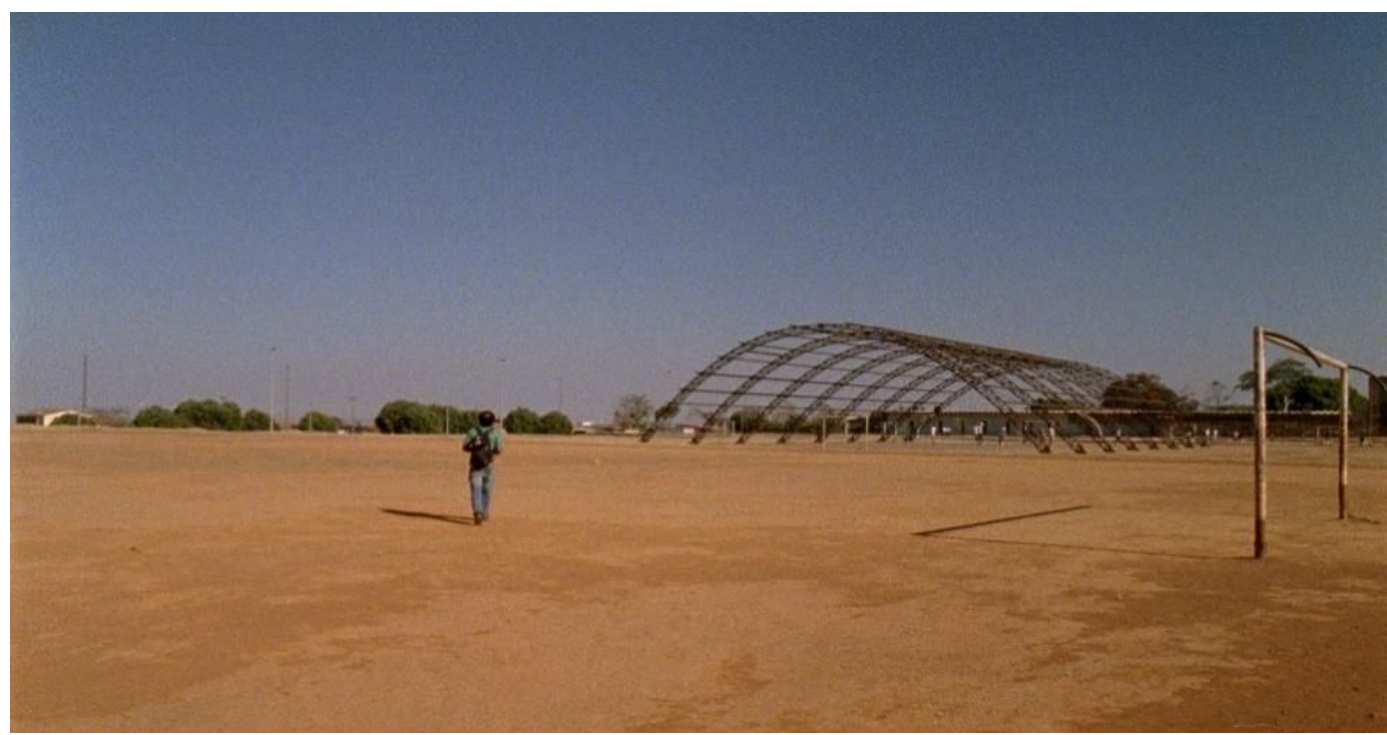

Figura 1: Cena do filme "A cidade é uma só ?" Fonte: DVD, 77"33'. Acesso 12 ago. 2016.

Brasília fica fora da cidade, como defendia Clarice Lispector (2012, p.180).É na periferia da capital que os contrastes se evidenciam em ambos os filmes e que, portanto, a crítica pode ganhar força e densidade. Partindo das bases heterogêneas da formação nacional, Adirley Queirós é capaz de organizar sua crítica, supostamente regional, como uma síntese nacional. Para falar de Brasília o diretor nunca filma o Plano Piloto; a promessa de Niemeyer e Lucio Costa se cumpre às avessas, o Plano Piloto é o lugar por onde todos passam, mas nunca param, onde ninguém se encontra e todos vagam na imensidão do Planalto Central. Só é possível representar Brasília se falarmos daquilo que falta, se a mostrarmos constituída e sustentada por ausências a apagamentos e, para o diretor, a forma encontrada para tornar a ausência presença é fazer emergir a história da Ceilândia. Só evidenciando o pacto de exclusão sobre o qual o país se assenta é possível enxergar as contradições da democracia brasileira.

Se Brasília é a expressão por excelência do futurismo, há uma descontextualização deste símbolo nos filmes em questão. Se havia por parte do governo a busca da superação do subdesenvolvimento, o Plano Piloto realiza uma "inversão desenvolvimentista" (HOLSTON 2010: 89) ao expulsar os candangos do centro e lançá-los nas cidades satélites. O Estado se torna diretamente responsável pelo processo de favelização de Brasília, ao passo que as medidas adotadas para superar a pobreza do país só fazem impulsionar a desigualdade. É deste paradoxo que "A cidade é uma só?" constitui-se em "contra-memória" (MESQUITA 2015:5) desta narrativa história. 


\section{Forma e política}

Assumidamente político, "A cidade é uma só?" retorna ao passado através de um confronto com o tempo presente. A questão territorial é a problemática central na qual a crítica do filme irá se organizar, seja na Campanha de Erradicação de Invasões, seja através da especulação imobiliária, atualizando signos de atuação do Estado e da política na vida atual de seus moradores.

A certeza de que o presente é consequência de uma promessa passada que não se cumpre é o que mobiliza a trama e ergue a crítica. Este procedimento de cobrança de dívida ocorre através de algumas operações dramáticas, como, por exemplo, quando Dildu, candidato a deputado distrital do PCN (Partido da Correria Nacional), promove sua campanha e um dos pontos de sua plataforma é o pagamento da indenização nunca recebida pelos moradores removidos. Ou, de maneira mais sutil, nas sequências de deslocamento em que os personagens que parecem nunca chegar a lugar algum. Ou, ainda, através de outro importante mecanismo de composição do discurso fílmico, o próprio procedimento de montagem: anárquico e dissensual (FELDMAN, 2012).

Adirley Queirós pontua, já na abertura da "A cidade é uma só?", o tom que o filme seguirá. Após uma animação que incendeia o Plano Piloto, o título do filme aparece e ao fundo um áudio retirado de um arquivo: "Aí está Brasília, tantos anos se passaram. A cidade que JK construiu com tanto entusiasmo. Uma cidade que vive como uma grande metrópole". Enquanto isso, a imagem que aparece na tela é a de um carro percorrendo as ruas estreitas da Ceilândia. O contraste promovido pela imagem e áudio reforça a denúncia do filme, com a justaposição de arquivos às imagens da realidade atual da Ceilândia provocando um questionamento do discurso oficial. Este procedimento percorre toda a narrativa, sempre contrastando entre a vida e a propaganda (MESQUITA, 2011). 


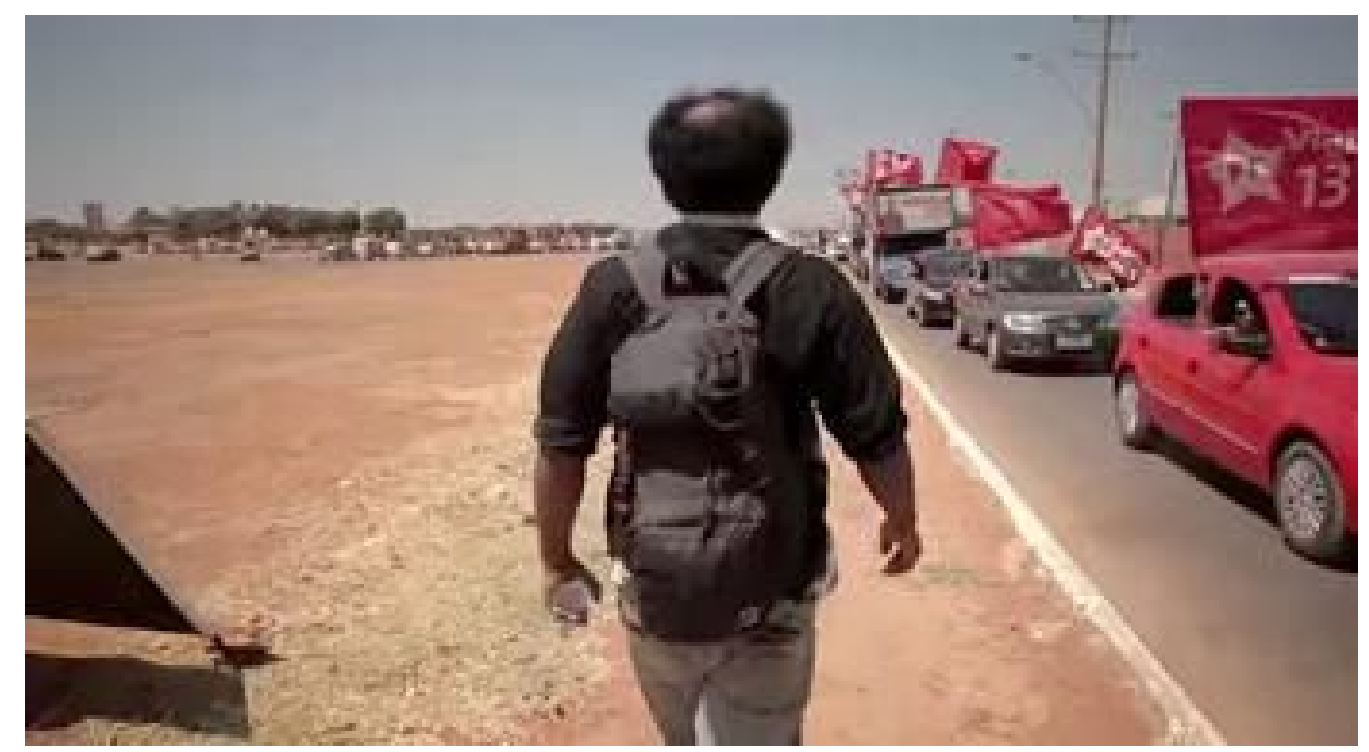

Figura 2: Cena do filme "A cidade é uma só?"

Fonte: DVD, 74"15'. Acesso 12 ago. 2016.

"A cidade é uma só?" se organiza em torno de três personagens. Zé Bigode é um pequeno especulador que expressa uma linha de continuidade histórica da política brasileira. Nancy é a voz narrativa que garante o fio condutor do filme, conferindo ao filme uma ancoragem documental com sua busca por algum documento que comprove seu relato. A personagem, juntamente com a equipe do filme, vasculha os arquivos de Brasília à procura do material do jingle que não consta nem mesmo nos arquivos públicos. A solução diante da falta de memória é ficcionalizar o documento para garantir a apreensão do fato histórico pela memória coletiva do país. E Dildu é o candidato do partido de um homem só, que também atua a partir de um jingle, marcando novamente o confronto entre vida e propaganda. 0 momento síntese é quando Dildu caminha solitariamente na contramão da carreata do então partido do poder, o PT, partido que Ihe é estranho. Nessa sequência, há o reconhecimento de uma distância intransponível entre a democracia representativa, sua forma de atuação e o povo. É uma sequência absolutamente desoladora, com Dildu completamente só, irrepresentável politicamente, vagando na contramão da imensidão do Planalto Central.

Enquanto a organização de "A cidade é uma só?" se dá a partir do deslocamento e interação de três núcleos narrativos (Dildu, Zé do Bigode e Nancy), "Branco sai, preto fica" se organiza a partir de núcleos solitários. Sartana, Marquim e Dimas Cravalanças, os personagens, nunca são filmados em conjunto, evidenciando não apenas o caráter opressor do território urbano, onde qualquer tipo de interação inexiste (como se o tempo inteiro a cidade 
tentasse expelir aqueles personagens que, a duras custas, sobrevivem no limite do perímetro urbano), mas, acima de tudo, a opção por articular a narrativa através destes núcleos solitários, rompendo com um possível sentimento de pertencimento coletivo, firmando um pacto de mutilação identitária e social.

Diferente de "A cidade é uma só?", onde a narrativa se estrutura em torno de um resgate do passado como tentativa de compreender o presente, "Branco sai preto fica" trata de uma experiência futura, em que a população periférica negra segue marginalizada, segregada e mutilada.

O filme parte de um evento real ocorrido em 1986, no baile black do Quarentão, onde, em uma batida policial, o comandante - o representante do Estado brasileiro - ordena aos brados: "Branco sai, e preto fica. Porra!". O preto fica, para ser chacinado, para ser mutilado, para a violência institucionalizada enquanto o branco pode se retirar. Dois dos personagens da trama sofrem em seus corpos os impactos dessa política pública: Marquim fica paraplégico, e passa a viver em uma cadeira de rodas, enquanto Sartana tem sua perna amputada após ser atropelado pela cavalaria. Em 2070, o agente terceirizado pelo Estado brasileiro, Dimas Cravalanças, é enviado para investigar os crimes cometidos pelo Estado contra a população negra periférica. A investigação do ocorrido de 1986 deve se converter em uma prova fundamental para incriminar o Estado.

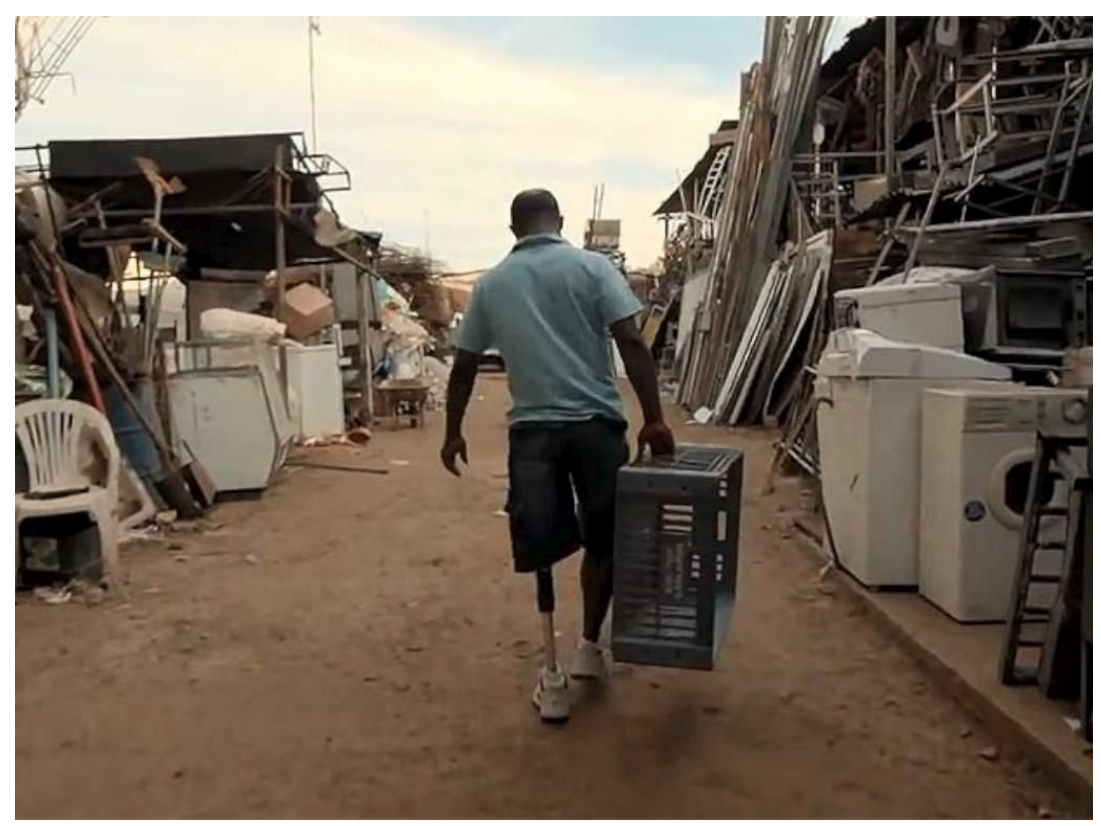

Figura 3: Cena do filme "Branco sai, preto fica" Disponível- DVD 13"40'. Acesso 20 de out. de 2016. 
Curioso notar que, neste panorama de cobrança de uma dívida histórica, Adirley Queirós problematiza a dimensão espaço e tempo por meio do prolongamento do trauma. $\mathrm{O}$ diretor distancia-se de uma representação idealizada do passado, numa tentativa de irromper com a paralisia causada pela nostalgia; o passado é marcado por música, massacre, amizade e preconceito. O que interessa ao diretor não é a rememoração ou mesmo a partilha do trauma, mas a maneira como este será ressignificado, a forma como Marquim e Sartana vão agir sobre o trauma. Uma importante estratégia utilizada é a aproximação do futuro de 2070 com o presente 2014. A história do cinema é marcada por inúmeras ficções científicas em que as cidades são articuladas como importante marcadores de tempos futuros: Blade Runner (Ridley Scott, 1982), Metropolis (Fritz Lang, 1927), Alphaville (Jean-Luc Godard 1965). Existe aí uma encruzilhada formal e temporal; se nos gêneros de ficção científica apocalípticos é o futuro que é representado como lugar distante e distópico, "Branco sai preto fica" fica evidente que a distopia está no tempo presente. E no tempo futuro, de onde vem Dimas Cravalanças, "a vanguarda cristã assume o poder" e o Estado, que terceirizou seus serviços, perde seu portal de teletransporte, continuando a ser um Estado de negociatas cujas consequências recaem sobre o povo. Nas palavras de Cravalanças "Voltar, para quê? Que vou fazer nesse futuro?

Ao invés de uma excessiva 'psicologização' do trauma passado - da maneira como rebate em quem o viveu -, o filme o toma como catástrofe que antecede um presente sombrio. A perda contamina toda a mise-en-scène da atualidade, e terá repercussões direta no encaminhamento para o futuro, interrompido pela execução de uma vingança individual, mas que alveja toda uma concepção de cidade, um projeto nacional, uma ordem social e até um regime temporal (MESQUITA, 2015, p.13).

Marquim conspira sua vingança construindo uma bomba cultural, que será lançada no Plano Piloto; tudo aquilo que fora silenciado por tantos anos vai ecoar e explodir o aparelho político brasileiro. Dimas Cravalanças seria recompensado caso fosse capaz de evitar a "grande explosão", mas opta por não impor nenhum entrave para o lançamento da bomba.

Em "Branco sai preto fica", Adirley Queirós sintetiza a experiência das últimas décadas da democracia brasileira, através do olhar de jovens negros moradores da periferia da capital: perpetuação da violência, racismo institucionalizado, segregação espacial, retração política, predação ambiental. A constatação é a da "impossibilidade de constituição de um sujeito político em um 'território de precariedade" (RIZEK 2011 apud MACIEL e OLIVEIRA, 2015). A promessa feita pelo Estado reparador de justiça social, inclusão política e inserção no mercado não passam de ficção científica. O filme não sustenta, momento algum, qualquer ilusão; não é possível encontrar condições de superação dentro desse espaço de reprodução. 
A especulação distópica de Adirley Queirós chega a seu ponto máximo quando identifica a urgência de um marco zero, que, para ele, seria explodir Brasília, apagar o paradigma do apagamento. Ambos os filmes partem dessa premissa, seja o início de "A cidade é uma só?", quando a planta do Plano Piloto é incinerada, ou no final de "Branco sai, preto fica", no ato terrorista em que a bomba cultural é lançada no Plano Piloto.

A Brasília de Adirley Queirós é, de fato, uma dramática ficção. A capital é representada enquanto contra-utopia: modernista, desenvolvimentista, urbanística e democrática. Nestes termos, Brasília é o personagem principal em seus filmes. E é através deste personagem que o diretor evoca as principais contradições nacionais: segregação, racismo, autoritarismo, supressão, violência, exclusão, depredação. Brasília, o paradigma do apagamento, é o paradigma do Brasil.

\section{Referências}

ARANTES, Otília Beatriz Fiori (2012). Brasília no projeto moderno de Mário Pedrosa. In: XAVIER, Alberto e KATINSKY, Julio (org). (2012) Brasília: Antologia Crítica. São Paulo: Cosac \& Naify.

BERMAN, Marshall (1982). Tudo que é sólido desmancha no ar. São Paulo: Companhia de Bolso.

BEÚ, Edson (2013). Os filhos dos Candangos. Brasília sob o olhar da periferia. Brasília: Editora UnB, 2013.

BRASIL, André (2013). Quando o antecampo se avizinha. Duas notas sobre o engajamento em A cidade é uma só? Brasília: Revista Negativo, vol. 01 n. 01, julho/setembro. Disponível em http://periodicos.unb.br/index.php/revnegativo/article/view/15167/10853

BRECHT, Bertolt (2003). Perguntas de um operário que lê. In: Poemas 1913-1956. São Paulo: Editora 34.

CEVASCO, Maria Elisa (2001). Para ler Raymond Williams. São Paulo: Paz e Terra. CEBALLOS, Gomes Viviane (2014). Memórias, tramas e espaço: A história de Brasília construída pela fala dos moradores de Sobradinho-DF. Tese de doutorado apresentada ao Programa de Pós-Graduação em História, UNICAMP.

CHOAY, Françoise (2001). Alegoria do Patrimônio. São Paulo: Editora Estação Liberdade, 2001. (2015). O Urbanismo. São Paulo: Editora Perspectiva.

(2012). Brasília uma capital pré-fabricada. In: XAVIER, Alberto e KATINSKY, Julio (org). Brasília: Antologia Crítica. São Paulo: Cosac \& Naify. 
CORREA, José; GHIROTTO, Mariana (2016). Brasil: Crise do petismo e esgotamento do distributivismo extrativista, mimeo.

COSTA, Everaldo Batista; PELUSO, Marília Luiza (2013). Territórios da Memória Candanga na construção da capital do Brasil (1956-1971). In XIII Simpósio Nacional de Geografia Urbana. Ciência e Ação Política:Por uma Abordagem Crítica. Rio de Janeiro, RJ: UFRJ, Vol 01, p. 1-22.

COSTA, Lucio (2012). Ingredientes da concepção urbanística de Brasília. In: XAVIER, Alberto; KATINSKY, Julio (org). Brasília: Antologia Crítica. São Paulo: Cosac \& Naify.

FELDMAN, Ilana (2012). A Disputa pela cidade, debate com Adirley Queirós. In Festival Adaptação: A literatura no cinema, 3a edição. Semana de arte moderna de 1922: 90 anos, Rio de Janeiro, RJ, 8 a 18 de novembro 2012.

Disponível em: https://www.youtube.com/watch?v=Z4TtJMso9CE\&t=400s HOLSTON, James (2010). A cidade modernista: uma crítica a Brasília e sua utopia. São Paulo: Companhia das Letras.

KUBITSCHEK, Juscelino (2012). De Pampulha a Brasília - os caminhos da providência. In: XAVIER, Alberto; KATINSKY, Julio (org). Brasília: Antologia Crítica. São Paulo: Cosac \& Naify.

LISPECTOR, Clarice (2012). Nos primeiros começos de Brasília. In: XAVIER, Alberto e KATINSKY, Julio (org). Brasília: Antologia Crítica. São Paulo: Cosac \& Naify.

LÖWY, Michael (2005). Walter Benjamin: aviso de incêndio. Uma leitura das teses 'Sobre o conceito de história'. São Paulo: Boitempo.

LYNCH, Christian Edward Cyril (2014). Da monarquia à oligarquia. História institucional do pensamento político brasileiro (1822-1930). Rio de Janeiro: Editora Alameda.

MACIEL, Danielle; OLIVEIRA, Taiguara. Cultura, reparação e revanche em tempos de guerra: comentários sobre Branco sai, preto fica, de Adirley Queirós, no prelo.

MESQUITA, Claudia (2015). Memória contra utopia: Branco sai, preto fica (Adirley Queirós, 2014). XXVI Encontro da Compós- GT Fotografia, Cinema e Vídeo, São Paulo. Disponível em:

http://www.compos.org.br/biblioteca/compos-2015-1a0eeebb-2a95-4e2a-8c4b-c0f6999c1d34 2839.pdf Um drama documentário? - atualidade e história em A cidade é uma só? Belo Horizonte: Revista Devires, vol. 08, n.2, julho/dezembro., p.48-69,201. Disponível em: http://www.fafich.ufmg.br/devires/index.php/Devires/article/view/254 MOSER, Benjamin (2016). Autoimperialismo. Três ensaios sobre o Brasil. São Paulo: Crítica. 
NIEMEYER, Oscar (2012). Minha experiência de Brasília. In: XAVIER, Alberto e KATINSKY, Julio (org) Brasília: Antologia Crítica. São Paulo: Cosac \& Naify.

PEDROSA, Mario (2012). Reflexões em torno da nova capital. In: XAVIER, Alberto; KATINSKY, Julio (org.) Brasília: Antologia Crítica. São Paulo: Cosac \& Naify.

QUEIRÓS, Adirley (2015). Entrevista Adirley Queirós diretor de 'Branco sai, preto fica' entrevista a Fora de Quadro. Publicada em 19 de março de 2015. Disponível em:

https://foradequadro.com/2015/03/19/entrevista-adirley-queiros-diretor-de-branco-sai-preto-f

\section{ica/}

SABOIA, Luciana e SANDOVAL, Liz (2012). A cidade é uma só? Luta por reconhecimento na relação centro-periferia em Brasília. III Seminário Internacional Urbicentros, Salvador, BA, 22 a 24 de outubro de 2012. Disponível em:

\section{http://www.ppgau.ufba.br/urbicentros/2012/ST163.pdf}

SANCHEZ, Félix Ruiz (2017). A distonia da dominação: Como as elites colocaram poder político fora de compasso. In CHADAVERIAN, Pedro (org) 21 $1^{\text {a }}$ Century Brazil: Challenging economic orthodoxy under Lula years. Routledge, Londres.

SANTOS, Milton (2012). Brasília e o subdesenvolvimento brasileiro. In: XAVIER, Alberto; KATINSKY, Julio (orgs.) Brasília: Antologia Crítica. São Paulo: Cosac \& Naify.

SCHWARCZ, Lilia Moritz; STARLING, Heloísa (2014). Brasil: Uma biografia. São Paulo: Companhia das Letras.

VIRILIO, Paul (1993). O espaço crítico e as perspectivas do Tempo Real. São Paulo: Editora 34.

WILLIAMS, Raymond (2013). A Política e as Letras. São Paulo: Editora Unesp.

\section{Filmografia trabalhada:}

A cidade é uma só? Direção: Adirley Queirós. Produção: André Carvalheira por 400 filmes e Adirley Queirós por 5 norte produções. Intérpretes: Dilmar Durões; Wellington Abreu; Nancy Araújo; Marquim Tropa e outros. Roteiro: Thiago Mendonça e Adirley Queirós. Música: Marquinhos do Tropa, Diró. Brasil: Vitrine Filmes, 2011. DVD (80min), colorido.

Branco sai, preto fica. Direção: Adirley Queirós. Produção: Simone Gonçalves e Adirley Queirós. Intérpretes: Dilmar Durões; Wellington Abreu; Marquim Tropa, DJ Jamaika, Shockito e outros. Roteiro: Adirley Queirós. Música: Marquinhos do Tropa, Diró. Brasil: Vitrine Filmes, 2014. DVD (93min), colorido.

\section{Filmografia citada:}


Alphaville, a estranha aventura de Lemmy Caution. Direção: Jean-Luc Godard. Produção: André Michelin. Intérpretes: AKim Tamiroff, Anna Karina, Eddie Constantine, Howard Vernon, Lazsló Szábó e outros. Roteiro: Jean-Luc Godard e Paul Éluard. Música: Paul Misraki. França e Itália: Athos Films; Chaumiane Films e Filmstudio, c 1965 (99 min), preto e branco.

Blade Runner. Direção: Riddley Scott. Produção: Michael Deeley. Intérpretes: Harrison Ford; Rutger Hauer, Sean Young; Edward James Olmos e outros. Roteiro: Hampton Fancher e David Peoples. Música: Vangelis. Los Angeles: Warner Brothers, c 1991. 1 DVD (117min), colorido. Produzido por Warner Video Home. Baseado na novella "Do androids dream of electric sheep?" de Philip K. Dick.

Conterrâneos velhos de guerra. Direção: Vladimir Carvalho. Produção: Vladimir Carvalho. Roteiro: Vladimir Carvalho. Interpretes: Othon Bastos, Pompeu de Souza, Oscar Niemayer e outros. Música: Zé Ramalho .Brasil: Vertovisão, c 1990 (175min), colorido.

Metrópoles. Direção: Fritz Lang. Produção: Eric Pommer. Intérpretes: Brigitte Helm, Alfred Abel, Rudolf Klein-Roge, Theodor Loos, Fritz Rasp, Gustav Fröhlich e outros. Roteiro: Thea von Harbou Música: Gottfried Huooertz. Alemanha: UFA, c1927 (148min), preto e branco. 